\title{
R2P: From Idea to Norm—and Action?
}

\author{
Ramesh Thakur and Thomas G. Weiss **
}

\section{Abstract}

The most dramatic normative development of our time-comparable to the Nuremberg trials and the 1948 Convention on Genocide in the immediate aftermath of World War II-relates to the 'responsibility to protect', the title of the 2001 report from the International Commission on Intervention and State Sovereignty. It no longer is necessary to finesse the tensions between sovereignty and human rights in the UN Charter; they can now be confronted because sovereignty no longer implies the license to kill. This essay outlines the origins of the R2P idea, describes the background factors in the 1990s that paved the way for the advancement of this norm by norm entrepreneurs, champions, and brokers. It continues with an account of the process by which the ICISS arrived at its landmark report, a description of the sustained engagement with the R2P agenda from 2001, when the ICISS report was published, to its adoption at the 2005 World Summit. The essay concludes with a sketch of the tasks and challenges that lie ahead to move R2P from a norm to a template for policy and action.

\footnotetext{
${ }^{* *}$ Ramesh Thakur is the Foundation Director of the Balsillie School of International Affairs and professor of political science at the University of Waterloo; Thomas G. Weiss is Presidential Professor of Political Science and Director of the Ralph Bunche Institute for International Studies, The CUNY Graduate Center. This article draws on their forthcoming book, The United Nations and Global Governance: An Unfinished Journey (Bloomington: Indiana University Press, 2009).
} 
The most fundamental human right is to life itself. Indeed, what could be more fundamental to a working system of global governance, however defined and however rudimentary? As Pope Benedict XVI put it in his address to the United Nations General Assembly in New York in April 2008, ‘[r]ecognition of the unity of the human family, and attention to the innate dignity of every man and woman, today find renewed emphasis in the principle of the responsibility to protect...this principle has to invoke the idea of the person as image of the Creator'. ${ }^{1}$ But establishing a universal standard to protect life under the most extreme threats represents a normative challenge because outsiders wishing to protect or assist affected populations confront the harsh reality of the nonintervention principle enshrined in Article 2(7) of the UN Charter.

Possibly the most dramatic normative development of our time-comparable to the Nuremberg trials and the 1948 Convention on Genocide in the immediate aftermath of World War II—relates to the use of military force to protect human beings. The publication of Global R2P reflects the fact that no longer is it necessary to finesse the tensions between sovereignty and human rights in the Charter; they can now be confronted. Sovereignty no longer implies the license to kill. Or, as Princeton University’s Gary Bass puts it in his masterful history of nineteenth-century efforts to halt mass atrocities, "We are all atrocitarians now—but so far only in words, and not yet in deeds."2

A norm can be defined statistically to mean the pattern of behaviour that is most

\footnotetext{
${ }^{1}$ Pope Benedict XVI, 'Address to the General Assembly of the United Nations', UNO, New York (Vatican City: Holy See Press Office, 18 April 2008).

2 Gary J. Bass, Freedom's Battle: The Origins of Humanitarian Intervention (New York: Knopf, 2008), 382.
} 
common or usual, or the 'normal curve', a widely prevalent pattern of behaviour. Alternatively, it can be defined ethically, to mean a pattern of behaviour that should be followed in accordance with a given value system —or the moral code of a society — a generally accepted standard of proper behaviour. In some instances, the two meanings may converge in practice. In most cases, they will complement each other, but in some cases, they may diverge. An especially good illustration of divergence is the difficulty in operationalizing the norm of the responsibility to protect as agreed to by heads of government meeting at the 2005 World Summit and now commonly referred to as R2P.

Nonetheless, no idea has moved faster in the international normative arena than the 'responsibility to protect' the title of the 2001 report from the International Commission on Intervention and State Sovereignty (ICISS). ${ }^{3}$ Over time, domestic and international jurisdictions are blurring, which became most evident with the willingness—-sometimes authorized by the United Nations, sometimes by regional organizations_-to shelve sacrosanct sovereignty by using military force for human protection purposes in the 1990s.

Created from the ashes of the Second World War with the allies determined to prevent a repeat of Adolf Hitler's abominations, the United Nations for most of its existence has focused far more on external aggression than internal mass killings. Yet Nazi Germany was guilty of both. Unlike aggression against other countries, the systematic and large-scale extermination of Jews was a new horror. In this new century, the world organization is at long last elevating the doctrine of preventing

\footnotetext{
${ }^{3}$ International Commission on Intervention and State Sovereignty, The Responsibility to Protect (Ottawa: International Development Research Centre, 2001).
} 
mass atrocities against people to the same level of collective responsibility as preventing and repelling armed aggression against states.

Traditional warfare is the use of force by rival armies of enemy states fighting over a clash of interests: us against them. Collective security rests on the use of force by the international community of states to defeat or punish an aggressor: all against one. Traditional peacekeeping involves the insertion of neutral and lightly armed thirdparty soldiers as a physical buffer between enemy combatants who have agreed to a ceasefire. Peace enforcement accepted the use of force by better armed—but still neutral—international soldiers against spoilers.

R2P is a more sophisticated, and politically a far more broadly acceptable, reformulation of the more familiar 'humanitarian intervention'. It differs in that it refers to the use of military force by outsiders for the protection of victims of mass atrocities. R2P redefines sovereignty as responsibility and locates the responsibility in the first instance with the state, but it argues that if the state is unwilling or unable to honour the responsibility, or is itself the perpetrator of atrocities against its people, then the residual responsibility to protect victims of atrocity crimes shifts to the international community of states, acting ideally through the Security Council.

R2P has a decided UN flavour. Its roots are to be found in statements by former Secretary-General Kofi Annan and the norm gives pride of place to the UN if the international community of states is to honour its international responsibility to protect—and if the norm is to be the basis of a new international consensus, this can only come about in the UN forum. 
The purpose of this article is to 'contextualize' R2P within current efforts to understand the web of 'global governance' that constitutes the few elements of international society and order that Hedley Bull so assiduously pursued in the face of ‘international anarchy'. ${ }^{4}$ How, in short, do we build an international system that responds to threats like mass murder and mass ethnic cleansing in the absence of a central authority?

We define 'governance' as the sum of laws, norms, policies, and institutions that define, constitute and mediate relations between citizens, society, market, and the state — the wielders and objects of the exercise of public power. 'Global governance'-which can be good, bad, or indifferent—refers to collective problemsolving arrangements. These may be visible but quite informal (e.g., practices or guidelines) or temporary units (e.g., coalitions). But they may also be far more formal, taking the shape of rules (laws, norms, codes of behaviour) as well as constituted institutions and practices (formal and informal) to manage collective affairs by a variety of actors (state authorities, intergovernmental organizations, civil society organizations, and private sector entities).

Global government would imply an international system with at least some of the capacities of national governments, notably, the power to control or repel threats, to raise revenues, allocate expenditures, redistribute incomes, and require compliance from citizens as well as ensure their rights. We clearly do not have anything resembling that. Global governance implies systems with imperfections and

\footnotetext{
${ }^{4}$ Hedley Bull, The Anarchical Society: A Study of Order in World Politics (New York: Columbia University Press, 1977).
} 
limitations—in a phrase, international cooperation where there is no global government, only states mostly pursuing their own national or regional interests. That we do have.

This essay in this new journal begins with truth in packaging—Ramesh Thakur was an ICISS commissioner and Thomas G. Weiss was its research director. We present the story of the journey of R2P from an idea to a global norm now in drastic need of implementation. The United Nations is a vital part of the story of contemporary global governance, and the astonishingly rapid journey of R2P from an idea to the center of the international normative, policy, and institutional arenas—providing us with a powerful and persuasive way to analyze contemporary international organization. When Secretary-General Kofi Annan issued his famous 'challenge of humanitarian intervention' in September 1999, he provoked such a furious backlash from so many countries that some wondered about his future in the UN. Yet a mere six years later, the norm was endorsed by the world leaders gathered at the UN. Annan called it one of his 'most precious of all' achievements. ${ }^{5}$

We begin by outlining the origins of the R2P idea and then describe the background factors in the 1990s that paved the way for the advancement of this norm. Next, we describe the main actors in the story: the norm entrepreneurs, champions, and brokers, followed by an account of the process by which the ICISS arrived at its landmark report on R2P. This is followed by a description of the sustained engagement with the R2P agenda from 2001, when the ICISS report was published, to its adoption at the 2005 World Summit. We end with a sketch of the tasks and challenges that lie ahead

5 Kofi Annan, 'A Progress Report on UN Renewal', Speech to the UN Association-UK, London, 31 January 2006, New World, April-June 2006, p. 8. 
to move R2P from a norm to a template for policy and action.

\section{Roots and Origins of the R2P Idea}

From one point of view, the idea of sovereignty as responsibility is not all that new or fresh. Rather, it has a long evolutionary pedigree; ‘[T]he principle of "responsibility to protect” was considered by the ancient ius gentium as the foundation of every action taken by those in government with regard to the governed', Pope Benedict XVI told UN diplomats. While the responsibility to protect 'has only recently been defined...it was always present implicitly at the origins of the United Nations, and is now increasingly characteristic of its activity'. ${ }^{6}$ The ICISS report consolidated a number of disparate trends and borrowed language first developed by Francis M. Deng — currently the Special Representative of the Secretary-General for prevention of genocide and at the time the Special Representative on internally displaced persons (IDPs) — and Roberta Cohen to help address the problem of IDPs. ${ }^{7}$ Rather than create a new norm, ICISS registered and dramatized a norm shift already underway and found language to make it more palatable to nay-sayers.

The importance of sovereignty as the key organizing principle of the modern world order needed and received a strong affirmation in the ICISS report. It took pains to emphasize that a cohesive and peaceful international system is more likely to be achieved through the cooperation of effective and legitimate states, confident of their place in the world, than in an environment of fragile, collapsed, fragmenting or generally chaotic states. Sovereignty provides order, stability, and predictability in

\footnotetext{
${ }^{6}$ Pope Benedict XVI, 'Address to the General Assembly of the United Nations'.

${ }^{7}$ For details, see Thomas G. Weiss and David A. Korn, Internal Displacement: Conceptualization and Its Consequences (London: Routledge, 2006).
} 
international relations; it is not merely a pretext for abuse.

As such, it implies a dual responsibility: externally, to respect the sovereignty of other states, and internally, to respect the dignity and basic rights of all the people within the state. Re-conceptualizing sovereignty as responsibility has a threefold significance. First, it implies that the state authorities are responsible for the functions of protecting the safety and lives of citizens and promotion of their welfare. Second, it suggests that national political authorities are responsible to the citizens internally and to the international community of states through the United Nations. And third, it means that the agents of state are responsible for their actions, that is to say, they are accountable for their acts of commission and omission.

This is a less radical departure from established precept and practice than it appears. The authority of the state is nowhere regarded as absolute. Internally, it is constrained and regulated by constitutional power sharing arrangements. It is shared between different levels of governmental authorities, from the local through the provincial to the national. And it is distributed among different sectors of authorities, such as the legislature, executive, judiciary, and bureaucracy.

As it happens, one of the best examples is India, a powerful country that expresses strong opposition to 'humanitarian intervention'. ${ }^{8}$ The fundamental rights in the Indian constitution guarantee the dignity and worth of individuals essentially against the state, and empower the judiciary to monitor and enforce state compliance. That is, the state is responsible and can be held accountable for acts of commission that

\footnotetext{
8 The following examples are drawn from Ramesh Thakur, The Government and Politics of India (London: Macmillan, 1995).
} 
violate citizens’ rights.

At the same time, several of India's independence leaders also believed that liberty is an empty abstraction to the hungry, and that freedom is meaningful only with economic security. In the light of India’s poverty, 'economic rights' (for example, the right to an adequate means of livelihood) could not realistically be enshrined as a basic right enforceable in the courts, but they were enshrined as ideals. The Indian Constitution accordingly incorporated them as directive principles, describing them as 'fundamental in the governance [sic] of the country and it shall be the duty of the state to apply these principles in making laws'. Some of these are in the nature of socio-economic rights, except that they cannot be enforced through the courts. When critics and political opponents criticize the government for failure to honour the directive principles, in essence they are arguing for holding the state responsible for acts of omission.

Internationally too, sovereignty is understood as embracing responsibility, in human rights covenants, UN efforts, and state practice itself. The UN Charter is an example of an international obligation voluntarily accepted by member states. In granting membership to the United Nations, the members welcome the signatory state as a responsible new member of the community of nations. At the same time, the state itself in signing the Charter, accepts the responsibilities of membership flowing from that signature. There is no transfer or dilution of the status of state sovereignty. But there is a necessary change in the exercise of sovereignty: from sovereignty as control to sovereignty as responsibility in both internal functions and external duties. 
The normative advances of the responsibility to protect can in no small measure be traced back to early efforts by the Brookings Project on Internal Displacement to give concrete meaning to the mandate of the Special Representative of the SecretaryGeneral for Internally Displaced Persons. Although the ICISS never formally acknowledged the parentage of the idea, Lloyd Axworthy-who as Canadian foreign minister launched the commission—has written: ‘[T]he first time I heard the notion of “responsibility to protect” was when Deng visited me in Ottawa and argued for a clear commitment by the international community to deal with the IDP issue' ${ }^{9}$

In his work on behalf of IDPs, Deng introduced into the literature on internal displacement a concept that had been developed by him, William Zartman, and other scholars in their work on governance in Africa. ${ }^{10}$ Deng's eventual colleague and project co-director at the Brookings Institution, Roberta Cohen, emphasized the international dimensions of protection. 'Sovereignty,' she wrote in 1991, 'carries with it a responsibility on the part of governments to protect their citizens’. ${ }^{11}$ Deng explained its origins in work begun in the late 1980s to see how the end of the Cold War changed the way that conflict and conflict resolution were perceived in Africa. It was a way of squaring the circle, to reconcile the seemingly clashing principles of state sovereignty and nonintervention, on the one hand, with the need to halt the worst

\footnotetext{
${ }^{9}$ Lloyd Axworthy, Navigating a New World: Canada's Global Future (Toronto: Alfred A. Knopf Canada, 2003), p. 414. Gareth Evans has made clear this historical link in The Responsibility to Protect: Halting Mass Atrocity Crimes Once and for All (Washington, DC: Brookings Institution, 2008).

10 See, for example, Francis M. Deng and I. William Zartman, eds., Conflict Resolution in Africa (Washington, DC: Brookings Institution, 1991); Francis M. Deng and Terrence Lyons, eds., African Reckoning: A Quest for Good Governance (Washington, DC: Brookings Institution, 1998); and Francis M. Deng, 'Reconciling Sovereignty with Responsibility: A Basis for International Humanitarian Action', in John W. Harbeson and Donald Rothschild, eds., Africa in World Politics: Post-Cold War Challenges (Boulder, Colo.: Westview, 1995), pp. 295-310.

11 Roberta Cohen, Human Rights Protection for Internally Displaced Persons (Washington, DC: Refugee Policy Group, 1991), p. 1.
} 
kinds of abuse of human rights on the other hand, and even to intervene militarily in the most egregious of cases.

This conceptualization to address the phenomenon of internal displacement then gained momentum with Annan’s articulation of ‘two sovereignties' in the late 1990s, and the formulation of the responsibility to protect in 2001. As a result, the characteristics of a sovereign — territory, authority, population, independencespelled out in the 1934 Montevideo Convention on the Rights and Duties of States have been complemented by another: a modicum of respect for human rights. State sovereignty is considerably less sacrosanct today than in 1945 . When a state is manifestly incapable or unwilling to do so and peaceful means fail, the resort to international judicial pursuit, sanctions, or even outside military force remains a possibility. The threshold for non-consensual intervention is high-not merely substantial human rights abuses but genocide or ethnic cleansing-but the fact that it remains a policy option represents significant new middle ground in international relations.

While a number of the world's most abusive governments would disagree, nonetheless a normative consensus is emerging in international society about a state's responsibilities and accountabilities both to domestic and international constituencies. Abusers that are major powers (e.g. China and Russia) or resource-rich (e.g. Saudi Arabia) are of course able to exercise their sovereignty with little fear of forceful outside intervention. However, it is becoming increasingly difficult for states to claim the prerogatives of sovereignty unless they meet internationally agreed responsibilities, which include protecting the human rights of, and providing life-sustaining assistance 
to, all those within its jurisdiction. Failure to meet obligations legitimises high-decibel levels of criticism and intrusion and, when the politics are right, even outside intervention by the United Nations and the community of responsible states, or a coalition of them, against a member of their club that misbehaves egregiously.

\section{Background Factors}

Going to war was an acknowledged attribute of state sovereignty and war itself was an accepted institution of the Westphalian system with distinctive rules, etiquette, norms, and stable patterns of practices to govern armed conflicts. ${ }^{12}$ In that quasiHobbesian world barely removed from the state of nature, the main protection against aggression was countervailing power, which increased both the cost of victory and the risk of failure. Since 1945, the UN has spawned a corpus of law to stigmatize aggression and create a robust norm against it. The world organization exists to check the predatory instincts of the powerful towards the weak — one of the most enduring but not endearing lessons of history—whether in domestic jurisdictions inside state borders or in international relations. Now there are significant restrictions on the authority of states to use force either domestically or internationally.

A further challenge to the Westphalian order came with the adoption of new standards of conduct for states in the protection and advancement of international human rights, one of the great achievements of the twentieth century. The UN Charter contains an inherent tension between the intervention-proscribing principle of state sovereignty and the intervention-prescribing principle of human rights. Individuals became subjects of international law as bearers of duties and holders of rights under a

12 See Kalevi J. Holsti, War, the State, and the State of War (Cambridge: Cambridge University Press, 1996). 
growing corpus of human rights and international humanitarian law treaties and conventions: the Charter, Universal Declaration of Human Rights and the two Covenants, the Geneva Conventions and its Additional Protocols, and the two Conventions prohibiting torture and genocide, and so on.

Over time, the chief threats to international security have come from violent eruptions of crises within states, including civil wars, while the goals of promoting human rights and democratic governance, protecting civilian victims of humanitarian atrocities, and punishing governmental perpetrators of mass crimes have become more important. With weapons of mass destruction (WMDs), and nuclear weapons in particular, doctrines and strategies for their use and deployment emphasized mass casualties amongst civilians as the main intended target. Even with conventional weapons, the emphasis has shifted from main battle tanks and bombers to small arms as the weapon of choice in contemporary armed conflicts. Moreover, noncombatants dying form conflict related starvation and disease now vastly outnumber troops killed directly in warfare, by a ratio of up to 9:1. The 'maintenance of international peace and security', for which primary responsibility is vested in the Security Council, needs to translate in practice to the protection of civilians. Given the changing nature and victims of armed conflict, the need for clarity, consistency, and reliability in the use of armed force for civilian protection now lies at the heart of the UN's credibility.

In a number of cases in the 1990s, the Security Council's imprimatur covered the use of force with the primary goal of humanitarian protection and assistance in: the protection of Kurds after the Gulf War, the proclamation (no matter how ineffectually) of UN safe areas in Bosnia, the delivery of humanitarian relief in 
Somalia, the restoration of the democratically elected government of Haiti, and the deployment of the multinational Kosovo Force (KFOR) in Kosovo after the 1999 war. ${ }^{13}$

The proliferation of complex humanitarian emergencies after the end of the Cold War, and the inappropriateness of the classical tenets of UN peacekeeping for dealing with them, ${ }^{14}$ highlighted the inherent tension between the neutrality and impartiality of traditional peacekeeping and the partial consequences of peace enforcement. The Brahimi Report confronted the dilemma squarely and concluded that political neutrality has often degenerated into military timidity and the abdication of the duty to protect civilians. Impartiality should not translate into complicity with evil. While striving to remain impartial, the UN should soften its principle of neutrality between belligerents in favour of 'adherence to the principles of the Charter and to the objectives of [the] mandate'. ${ }^{15}$

There is yet another key background factor behind the rise of R2P, namely the softening of sovereignty in so many of its empirical dimensions. It has become commonplace to note that under the impact of globalization, political, social, commercial-economic, environmental, and technological influences cross borders without passports. The total range of cross-border flows and activities has increased while the proportion subject to control and regulation by governments has diminished. National frontiers are becoming less relevant in determining the flow of ideas,

\footnotetext{
13 See Brian D. Lepard, Rethinking Humanitarian Intervention (University Park: Pennsylvania State University Press, 2002), pp. 7-23.

${ }^{14}$ See Ramesh Thakur and Carlyle A. Thayer, eds., A Crisis of Expectations: UN Peacekeeping in the 1990s (Boulder: Westview, 1995).

15 Report of the Panel on United Nations Peace Operations, UN Document A/55/305-S/2000/809, 21 August 2000, para. 50.
} 
information, goods, services, capital, labour, and technology. The speed of modern communications makes borders increasingly permeable, while the volume of crossborder flows threatens to overwhelm the capacity of states to manage them.

The erosion of the once sacrosanct principle of national sovereignty is rooted in the reality of global interdependence: no state is an island sufficient unto itself any longer. Moreover, the proliferation of states has led to the creation and recognition of many states that are weak, fragile, disrupted, collapsed or failed. For example, just as East Timor has become a de facto protectorate of Australia, so too is the security (internal and external) and economic viability of Kosovo underwritten ultimately by Europe; meanwhile, Somalia continues to hobble along as a state without many of the traditional attributes of statehood.

\section{'Humanitarian Intervention' in the 1990s}

The cumulative effect of these changes has posed significant conceptual, policy, and operational challenges to the notion of state sovereignty. ICISS responded to a series of military-civilian interactions in humanitarian crises, ${ }^{16}$ which confronted directly the divergent reactions—or rather, the non-reactions—by the Security Council. For instance, in 1994, intervention was too little and too late to halt or even slow the murder of what may have been as many as 800,000 people in the Great Lakes region of Africa. In 1999, the formidable North Atlantic Treaty Organization (NATO) bypassed the Council and waged war for the first time in Kosovo. But many observers saw the 78-day bombing effort as being too much, too late, too little (in ruling out the use of ground troops) and too counterproductive, perhaps creating as

16 For further details, see Thomas G. Weiss, Military-Civilian Interactions: Humanitarian Crises and the Responsibility to Protect (Lanham, Md.: Rowman \& Littlefield, 2004), $2^{\text {nd }}$ edition, pp. 191-214. 
much human suffering among IDPs and refugees as it relieved. In both cases, the Security Council failed to act expeditiously and authorize the use of deadly force to protect vulnerable populations. In both cases, many—but not all—human rights advocates and humanitarian agencies supported the military protection of civilians whose lives were threatened, thereby exposing the glaring normative gap for collective action more clearly than in the past.

If the UN was going to be relevant, it had to engineer a basis for international involvement in the ugly civil wars that produced such conscience-shocking suffering. The earlier debate about whether humanitarian disasters qualified as 'threats to international peace and security' had resolved itself because so many humanitarian crises had been the object of Security Council action for precisely these reasons.

Our point of departure in reviewing the thrust of the ICISS should be made clear at the outset: the lack of reaction in Rwanda represents a far more serious threat to international order and justice than the Security Council's paralysis in Kosovo. Past or potential victims undoubtedly would agree with this judgment. For instance, the most thorough survey to date of victims in war zones suggests that there is too little rather than too much humanitarian intervention. Fully two-thirds of civilians under siege who were interviewed in twelve war-torn societies by the International Committee of the Red Cross (ICRC) want more intervention and only 10 percent want none. ${ }^{17}$ In addition, a 2005 mapping exercise of operational contexts for humanitarian agencies finds that recipients 'are more concerned about what is

\footnotetext{
${ }^{17}$ Greenberg Research, The People on War Report (Geneva: ICRC, 1999), p. xvi.
} 
provided than about who provides it'. ${ }^{18}$

\section{Actors}

Norms neither arise nor are converted into laws and regimes by some mysterious process. They require identifiable agents. The crucial actors promoting and shepherding R2P through the maze of UN politics can be broken down into norm entrepreneurs, champions, and brokers.

As a norm entrepreneur, the UN Secretary-General is a unique international actor with distinctive characteristics and bases of authority and influence, but also with limitations. ${ }^{19}$ There were several moral pleas in 1999 from the future Nobel laureate, Kofi Annan. And if we fast forward to his speech in New York in March 2004 to commemorate the tenth anniversary of the Rwanda genocide, he regretted that he could and should have done more. ${ }^{20}$ He was driven similarly by his experience of being in charge of peacekeeping at the time of the Srebrenica massacre in 1995.

As Annan graphically told a 1998 audience at Ditchley Park, 'state frontiers...should no longer be seen as a watertight protection for war criminals or mass murderers' ${ }^{21}$

\footnotetext{
${ }^{18}$ Antonio Donini, Larry Minear, Ian Smillie, Ted van Baarda, and Anthony C. Welch, Mapping the Security Environment: Understanding the Perceptions of Local Communities, Peace Support

Operations, and Assistance Agencies (Medford, Mass.: Feinstein International Famine Center, June 2005), p. 53.

19 See Ramesh Thakur, The United Nations, Peace and Security: From Collective Security to the Responsibility to Protect (Cambridge: Cambridge University Press, 2006), ch. 14; and Simon Chesterman, ed., Secretary or General? The UN Secretary-General in World Politics (Cambridge: Cambridge University Press, 2007).

${ }^{20}$ Ramesh Thakur's notes from that event.

${ }^{21}$ Kofi A. Annan, The Question of Intervention: Statements by the Secretary-General (New York: UN, 1999), p. 7.
} 
He argued that human rights concerns transcended claims of sovereignty, a theme that he put forward more delicately a year later at the Millennium Summit. ${ }^{22}$ The reaction was loud, bitter, and predictable, especially from China, Russia, and much of the Third World. 'Intervention’ — for whatever reason, even humanitarian — remains taboo. ${ }^{23}$ The chorus of complaints in the General Assembly after Annan's remarks in September 1999 had a remarkably similar tenor to negative reactions in the Commission on Human Rights about many aspects of Deng’s mandate as a special representative of the Secretary-General. Diplomats are often out of touch with Comment [pr2]: You seem to capitalize opinion in developing countries around the world, which tend to be much more nuanced. ${ }^{24}$

It helped also that Annan, the only UN insider to have held the organization's top job, had an unmatched grasp of politics as they operated among member states and staff members. ${ }^{25}$ His explanation for the utility to the UN of outside intellectual energies is compelling:

There are certain issues that are better done outside and there are certain issues that can only be done inside... But take a look at the intervention issue.

I couldn't have done it inside. It would have been very divisive. And the member states were very uncomfortable because, as an organization,

\footnotetext{
22 Kofi A. Annan, The Question of Intervention and 'We the Peoples': The United Nations in the $21^{\text {st }}$ Century (New York: UN, 2000). For a discussion of the controversy surrounding the speech in September 1999, see Thomas G. Weiss, ‘The Politics of Humanitarian Ideas', Security Dialogue, vol. 31, no. 1 (2000), pp. 11-23.

${ }^{23}$ For an overview, see Mohammed Ayoob, 'Humanitarian Intervention and International Society', Global Governance, vol. 7, no. 3 (2001), pp. 225-30; and Robert Jackson, The Global Covenant: Human Conduct in a World of States (Oxford: Oxford University Press, 2000).

${ }^{24}$ For elaboration, see Thakur, The United Nations, Peace and Security, ch. 12, 'Developing Countries and the Eroding Non-intervention Norm'.

${ }^{25}$ For a discussion of policy-making and policy-breaking, see Ramesh Thakur and Thomas G. Weiss, 'United Nations “Policy”: An Argument with Three Illustrations', International Studies Perspectives vol. 10, no. 2 (2009), forthcoming.
} 
sovereignty is our bedrock and bible-here is someone coming with ideas which are almost challenging it. So I had to sow the seed and let them digest it but take the study outside and then bring in the results for them to look at it. I find that when you are dealing with issues where the member states are divided and have very strong views, and very strong regional views, if you do the work inside the discussions become so acrimonious that however good a document is, sometimes you have problems... But if you bring it from outside... they accept it. ${ }^{26}$

R2P's state champion from start to finish was Canada, a country strongly committed to UN-centred multilateralism, with a history of close engagement with the world organization, political credibility in both North and South, and a proud tradition of successful global initiatives. Foreign Minister Lloyd Axworthy initiated the establishment of the Commission in response to Annan's challenge in fall 1999. He was still the Minister when the Commission was assembled but retired from politics not long after. The Commission’s work continued under his successors as Foreign Minister, John Manley and Bill Graham. When Paul Martin succeeded Jean Chrétien as Prime Minister, again there was no break in the continuity, helped by a change in leadership not in government. There were also several other like-minded countries like Norway and Switzerland, as well as major foundations like MacArthur and other actors like the ICRC, which worked closely with ICISS in supportive advocacy.

The norm broker was the ICISS. Its mandate was to build a broader understanding of the tension between intervention and state sovereignty and to find common ground

26 Thomas G. Weiss, Tatiana Carayannis, Louis Emmerij, and Richard Jolly, UN Voices: The Struggle for Development and Social Justice (Bloomington: Indiana University Press, 2005), p. 378. 
for military intervention to support humanitarian objectives. Humanitarian imperatives and principles of sovereignty are reconciled through 'the responsibility to protect', a paraphrase of 'sovereignty as responsibility’ with some conceptual and enormous political consequences.

\section{ICISS Process}

The background factors and the range of actors engaged with the issue over the past decade go a long way towards explaining the movement of sovereignty as responsibility from the periphery to the centre of international relations in general and UN diplomacy in particular. The Canadian government’s initiative in September 2000 followed Annan’s poignant rhetorical question: ‘If humanitarian intervention is, indeed, an unacceptable assault on sovereignty, how should we respond to a Rwanda, to a Srebrenica — to gross and systematic violations of human rights that offend every precept of our common humanity?' 27 Given the supposedly wide disparity of views across the North-South divide-industrialized countries more enthusiastic in principle, developing countries more wary about providing a rationale for outside intervention-ICISS was co-chaired by persons from each camp (Gareth Evans and Mohamed Sahnoun, respectively) and its Commissioners were also evenly divided. But sovereignty as responsibility is not really a North-versus-South issue other than at a misleadingly superficial level, even though that is how, like so many other international issues, it is usually parsed. The extensive ICISS outreach and consultations offered evidence of how differences across and within regions-Africa, Asia, and Latin America — and between governments and civil society within

\footnotetext{
${ }^{27}$ Report of the Secretary-General on the Work of the Organization, UN Document A/54/1 (1999), p.
} 48. 
countries are varied and subtle.

Ten consultations in both the Northern and Southern Hemispheres sought the views of governments, scholars, intergovernmental and nongovernmental humanitarian actors, and journalists. ${ }^{28}$ The cacophony cannot be summarized except to say that what was most notable, from a historical perspective, is that nowhere did anyone argue that intervention to sustain humanitarian objectives is never justifiable. ${ }^{29}$ After the genocide in Rwanda, very few policymakers, pundits, or practitioners exclude protective intervention as a last resort that is necessary under some tragic contingency.

\section{From the Report to the World Summit, Filling the Policy Gap}

The ICISS final report was published with exceptionally bad timing in December 2001, very shortly after the terrorist attacks of September 11 . Understandably, the world's attention was preoccupied with the consequences of and responses to that horrific event. The subsequent invasion of Iraq and the ousting of Saddam Hussein by a U.S.-led coalition acting without UN authorization had a doubly damaging effect. First, as tensions mounted over 2002 and early 2003, few had the time to focus on R2P. Second, as the WMD justification for the war fell apart and claims of close links between Saddam's regime and al-Qaeda also proved spurious, the coalition of the willing—Australia, Britain, and the United States as the three main belligerent states—began retroactively to use the language of humanitarian intervention and R2P

28 Commission meetings were held in Ottawa (November 2000), Maputo (March 2001), New Delhi (June 2001), Wakefield, Canada (August 2000), and Brussels (September 2001). Round tables and consultative meetings were held, in chronological order, in Ottawa, Geneva, London, Maputo, Washington DC, Santiago, Cairo, Paris, New Delhi, Beijing and St. Petersburg.

29 They are reflected in Thomas G. Weiss and Don Hubert, The Responsibility to Protect: Research, Bibliography, and Background (Ottawa: International Development Research Centre, 2001), Part III. 
as the main plank of justification for their actions in Iraq. Thus Richard Haass, the former director of policy planning unit in the U.S. State Department and current president of the Council on Foreign Relations, spoke of sovereignty as responsibility and argued that when states fail to discharge their responsibility to fight terrorism, 'America will act-ideally with partners, but alone if necessary-to hold them accountable' ${ }^{30}$ If the comment was restricted to self-defence against cross-border terrorism, it was fine. But if the statement was to be extended to military intervention for human protection purposes, it posed serious problems.

Some of the ICISS commissioners argued strenuously in the public debate that Iraq would not have met the R2P test for intervention. ${ }^{31}$ Co-chair Gareth Evans, Commissioner Ramesh Thakur, and Research Director Thomas Weiss spoke and wrote extensively in the years following the publication of the report to multiple audiences: policy (intergovernmental and government officials), scholarly, and civil society. ${ }^{32}$ The Canadian government organized an extensive series of consultations with governments, regional organizations, and civil society forums, typically using the two co-chairs, as well as Thakur and Weiss (and some other ICISS members within their regions) to help promote the report. As the message resonated, many civil

\footnotetext{
30 Richard Haass, 'When Nations Forfeit their Sovereign Privileges', International Herald Tribune, 7 February 2003.

${ }^{31}$ Gareth Evans, 'Humanity Did Not Justify this War', Financial Times, 15 May 2003; Ramesh Thakur, 'Chrétien Was Right: It's Time to Redefine a “Just War”, Globe and Mail, 22 July 2003 and 'Iraq and the Responsibility to Protect', Behind the Headlines vol. 62, no.1 (Toronto: Canadian Institute of International Affairs, October 2004). However, one of the Commissioners, Michael Ignatieff, now a member of Parliament in Canada, justified the war.

32 The full list of Evans's extensive speeches and writings on R2P can be found in his book, The Responsibility to Protect, and on the website of the International Crisis Group: http://www.crisisgroup.org. Thakur's writings encompass a wide range of products from newspaper op-eds and scholarly articles to his book, The United Nations, Peace and Security. Weiss's writings are mainly academic, especially Humanitarian Intervention: Ideas in Action (Cambridge: Polity Press, 2007).
} 
society organizations began advocacy and dissemination work on their own as well.

Of course, Kofi Annan remained fully engaged with the issue.

The Secretary-General’s High-Level Panel on Threats, Challenges and Change, which included ICISS co-chair Gareth Evans, reaffirmed the importance of the terminology change from the deeply divisive 'humanitarian intervention' to 'the responsibility to protect'. It explicitly endorsed the ICISS argument that 'the issue is not the "right to intervene” of any State, but the "responsibility to protect” of every State' ${ }^{33}$ It proposed five criteria of legitimacy: seriousness of threat, proper purpose, last resort, proportional means, and balance of consequences. ${ }^{34}$ In a significant breakthrough for the growing acceptance of the new norm, China's official paper on UN reforms, published on 7 June 2005, noted that 'Each state shoulders the primary responsibility to protect its own population.... When a massive humanitarian crisis occurs, it is the legitimate concern of the international community to ease and defuse the crisis'. It went on to list the conditions and safeguards, including Security Council authorization, which form the core of the responsibility to protect. ${ }^{35}$ In the meantime in the United States, the Gingrich-Mitchell task force too endorsed the responsibility to protect, including calls for the norm to be affirmed by the Security Council and the General Assembly. ${ }^{36}$

\footnotetext{
33 High-level Panel on Threats, Challenges and Change, A More Secure World: Our Shared Responsibility (New York: United Nations document A/59/565, December 2004), para. 201, emphasis in original.

34 Ibid., para. 207.

35 Position Paper of the People's Republic of China on the United Nations Reforms (Beijing: 7 June 2005), downloaded from http://news.xinhuanet.com/english/2005-06/08/content_3056817_3.htm, accessed 1 October 2008, Part III.1, 'Responsibility to Protect'.

${ }^{36}$ American Interests and UN Reform: Report of the Task Force on the United Nations (Washington DC: US Institute of Peace, 2005), p. 15.
} 
In his own report before the World Summit, Annan made an explicit reference to ICISS and R2P as well as to the High-Level Panel, endorsed the legitimacy criteria, and urged the Security Council to adopt a resolution 'setting out these principles and expressing its intention to be guided by them' when authorizing the use of force. This would 'add transparency to its deliberations and make its decisions more likely to be respected, by both Governments and world public opinion' ${ }^{37}$

In the event, the responsibility to protect was one of the few substantive items to survive the negotiations at the World Summit in New York in September 2005. Some of the most supportive critics criticized the summit's emphasis on the state and the requirement for coercive measures to be authorized by the Security Council as constituting 'R2P lite', and others thought that the actual language in paragraphs 138139 of the World Summit Outcome Document was wordier and woollier than the ICISS version. ${ }^{38}$ We do not disagree, but nonetheless we see the document as a step forward in a long process.

The concept was given its own subsection title. ${ }^{39}$ The document makes clear the need for international intervention when countries fail to shield their citizens from, or more likely actively sponsor, mass-atrocity crimes. The language contains a clear, unambiguous acceptance by all UN members of individual state responsibility to protect populations from genocide, war crimes, ethnic cleansing, and crimes against

\footnotetext{
37 Kofi A. Annan, In Larger Freedom: Towards Development,Security and Human Rights for All. Report of the Secretary-General (New York: United Nations document A/59/2005, 21 March 2005), paras. 122-35.

${ }^{38}$ For an assessment, see Alex J. Bellamy, 'Whither the Responsibility to Protect?' Ethics and International Affairs vol. 20, no. 2 (2006), pp. 143-169.

392005 World Summit Outcome, adopted by UN General Assembly Resolution A/RES/60/1, 24 October 2005, paras. 138-40.
} 
humanity. Member states further declared that they 'are prepared to take collective action, in timely and decisive manner, through the Security Council...and in cooperation with relevant regional organizations as appropriate, should peaceful means be inadequate and national authorities are manifestly failing to protect their populations'. Leaders stressed 'the need for the General Assembly to continue consideration of the responsibility to protect populations from genocide, war crimes, ethnic cleansing, and crimes against humanity'. The heads of state and government who gathered in New York in New York 'stress[ed] the need for the General Assembly to continue consideration of the responsibility to protect populations from genocide, war crimes, ethnic cleansing, and crimes against humanity'. ${ }^{40}$ However, the legitimacy criteria-which would simultaneously make the Security Council more responsive to outbreaks of humanitarian atrocities than hitherto and make it more difficult for individual states or ad hoc 'coalitions of the willing' to appropriate the language of humanitarianism for geopolitical and unilateral interventions-were dropped. ${ }^{41}$

\section{R2P as Normative Advancement}

The most significant achievement of R2P is to fill a crucial normative gap. The clearest way to gauge the impact of this emerging norm is to situate the rapid evolution of attitudes and awareness. The political brouhaha over 'humanitarian intervention' provided the basis for compromise in the work by ICISS whose final report opens with words that could have come directly from Deng and Cohen's pen or word-processor:

\footnotetext{
40 Ibid.

${ }^{41}$ For a sceptical note on the utility of such criteria, see Alex J. Bellamy, 'R2P and the Problem of Military Intervention’, International Affairs vol. 84, no. 4 (2008), pp. 625-30.
} 
State sovereignty implies responsibility, and the primary responsibility for the protection of its people lies with the state itself. Where a population is suffering serious harm, as a result of internal war, insurgency, repression or state failure, and the state in question is unwilling or unable to halt or avert it, the principle of nonintervention yields to the international responsibility to protect. ${ }^{42}$

These developments are not, of course, without critics among states as well as analysts. A host of the usual suspects in the Third World (e.g., Algeria, Malaysia, Egypt, India, Cuba, the Sudan, and Venezuela) along with China and Russia oftentimes, but not always, are among the loudest critics. India, Algeria, and Russia together account for what may be 1.5 million IDPs and are clearly uneasy with any publicity about the plight of those people. ${ }^{43}$ They are joined by analytical critics ranging from those who fear it will become an instrument of abuse by the most powerful to others who worry that it will give the powerful an excuse to avoid international action. Thus, Mohammed Ayoob sees it as conjuring up ‘images of colonial domination under the guise of nineteenth-century "standard of civilization" doctrine';44 David Rieff questions whether 'it has actually kept a single jackboot out of a single human face'; 45 and for Alex Bellamy the language itself has been 'abused by states keen to avoid assuming any responsibility for saving some of the world's most vulnerable people'. ${ }^{46}$ Of course Washington drags its feet because it

\footnotetext{
42 ICISS, The Responsibility to Protect, p. xi.

${ }^{43}$ U.S. Committee for Refugees, World Refugee Survey 2005 (Washington, DC: USCR, 2005), p. 11. 44 Ayoob, 'Humanitarian Intervention and International Society', p. 84. For the context that drives Ayoob's skepticism, see Simon Chesterman, Michael Ignatieff, and Ramesh Thakur, eds., State Failure and the Crisis of Governance: Making States Work (Tokyo: UN University Press, 2005). ${ }^{45}$ David Rieff, A Bed for the Night: Humanitarianism in Crisis (New York: Simon \& Schuster, 2002), p. 15.

46 Alex J. Bellamy, 'Responsibility to Protect or Trojan Horse? The Crisis in Darfur and Humanitarian Intervention after Iraq’, Ethics \& International Affairs vol. 19, no. 2 (2005), p. 53.
} 
categorically refuses to have its military committed by others. Moreover, scepticism emanates from practitioners like the Calcutta Research Group’s Paula Banarjee who judges that sovereignty as responsibility 'is of little importance as the government defines both sovereignty and responsibility...[and] often sovereignty means powerlessness of marginal groups and responsibility is only to the so-called majority’. ${ }^{47}$

We are more sanguine about the potential consequences of having filled this normative gap as well as about the necessity for outside intervention and its beneficial impact. Even if the sun seems to have set for the moment, ${ }^{48}$ it could prove the prelude to a new dawn. The sea change in mainstream normative views since the beginning of the 1990s contrasts even more sharply with the experience of the 1970s. ${ }^{49}$ Three interventions with very substantial humanitarian pay-offs were not even partially framed or justified by the interveners in such terms. At that time, the notion of using outside military force when a sovereign state acted irresponsibly toward its citizens was simply too far from the mainstream of acceptable international relations. International order was firmly grounded in the inviolability of sovereignty, and therefore states were more attuned to their own unique political interests than to humanitarian imperatives. Specifically, India's invasion of East Pakistan in 1971, Tanzania's invasion of Uganda (1979) and Vietnam's invasion of Cambodia (1979) were unilateral efforts geared to regime change; and they all were explicitly justified as self-defence. In retrospect, all three are frequently cited as evidence of an emerging

\footnotetext{
47 Email to Thomas G. Weiss, 11 October 2005.

48 Thomas G. Weiss, 'The Sunset of Humanitarian Intervention? The Responsibility to Protect in a Unipolar World’, Security Dialogue, vol. 35, no. 2 (2004), pp. 135-153.

49 See Ramesh Thakur, 'Humanitarian Intervention', in Thomas G. Weiss and Sam Daws, eds., Handbook of the United Nations (Oxford: Oxford University Press, 2007), pp. 387-403; and Weiss and Hubert, The Responsibility to Protect, pp. 57-63.
} 
right to humanitarian intervention. Yet, none were approved by the Security Council—and Vietnam's was actually condemned.

Clearly the international normative climate is dramatically different, and in great measure along the lines recommended first by Deng and Cohen, later by the Secretary-General, and finally by the more visible ICISS. On some occasions, the fundamental rights of civilians assume relatively more weight than the prerogatives of states to act with impunity and hide behind the facade of sovereignty. UN authorization of military intervention is not of course an option against major powers as international tolerance for Russian and Chinese atrocities in Chechnya and Xinjiang aptly demonstrates. However, the good should not be an enemy of the best. Some action, even if inconsistent, is better than none.

The relationship between sovereignty and intervention is thus increasingly viewed as complementary rather than contradictory. Sovereignty is conceived as a conditional right dependent upon respect for a minimum standard of human rights and upon each state's honouring its obligation to protect its citizens. If a particular state is manifestly unwilling or unable to do so, or is actually the perpetrator of such crimes, the responsibility to protect them should be borne by the international community of states.

The sea change also reflected the Security Council's framing of issues, for instance its emphasis on vulnerable groups_-including Resolution 1261 that condemns the targeting of children, Resolution 1265 on the protection of civilians in armed conflict, Resolution 1325 that specifically addresses the impact of war on women, and 
Resolution 1400 that extends the UN mission in Sierra Leone mainly on the basis of IDPs. Former New York Times columnist Anthony Lewis is on target when he characterises the ICISS's framing of issues as 'the international state of the mind' ${ }^{50}$

None of this normative development took place in a vacuum. By redefining sovereignty as responsibility, the report addressed the demand-side of intervention, especially Rwanda. It would have been far more difficult for the ICISS to refine the interpretation of sovereignty had the egregious non-decision by the international community of states not led to hundreds of thousands of deaths.

The terrain on which the conceptual and policy contest over 'humanitarian intervention' has been fought is essentially normative. Norm displacement has taken place from the entrenched norm of non-intervention to the new norm of the responsibility to protect. The United Nations lies at the centre of this contest, both metaphorically and literally. The Charter, more than any other document, encapsulates and articulates the agreed consensus on the prevailing norms that give structure and meaning to the foundations of world order. And the international community of states comes together physically primarily within the UN's hallowed halls. It is not surprising, therefore, that the organization should be the epicentre of the interplay between changing norms and shifting state practice.

\section{International Criminal Pursuit, Filling the Institutional Gap}

Discussion and analyses of the protection of civilians and the prosecution of perpetrators have hitherto proceeded along separate lines. In fact they are two sides of

\footnotetext{
${ }^{50}$ Anthony Lewis, ‘The Challenge of Global Justice Now', Dæedalus, vol. 132, no. 1 (2003), p. 8.
} 
the same coin. ${ }^{51}$ The inter-related twin tasks are to protect the victims and punish the perpetrators. Both require substantial derogations to sovereignty, the first with respect to the norm of non-intervention and the second with respect to sovereign impunity up to the level of heads of government and state. At the same time, both require sensitive judgments: the use of external military force to protect civilians inside sovereign jurisdiction should first satisfy legitimacy criteria rooted largely in just war theory, while the prosecution of alleged atrocity criminals should be balanced against the consequences for the prospects and process of peace, the need for post-conflict reconciliation, and the fragility of international as well as domestic institutions.

We have witnessed what amount to revolutionary advances in the criminalization of domestic and international violence by armed groups and their individual leaders. 52 The law of the Charter governs when force may be used; international humanitarian law governs how force may be used. While the International Court of Justice (ICJ) deals with justice among states, increasing attention and sensitivity to human rights abuses and atrocities raise questions of individual criminal accountability. The international community of states has responded by drafting and adopting international legal instruments that ban mass atrocities. ${ }^{53}$

Having petitioned the League of Nations to outlaw 'acts of barbarism and vandalism'

51 See Ramesh Thakur and Vesselin Popovski, 'The Responsibility to Protect and Prosecute: The Parallel Erosion of Sovereignty and Impunity', in Yearbook of International Law and Jurisprudence (Oxford: Oxford University Press, 2008), pp. 39-61.

52 See Ramesh Thakur and Peter Malcontent, eds., From Sovereign Impunity to International Accountability: The Search for Justice in a World of States (Tokyo: UN University Press, 2004); and Edel Hughes, William A. Schabas, and Ramesh Thakur, eds., Atrocities and International Accountability: Beyond Transitional Justice (Tokyo: UN University Press, 2007).

53 See Robert Gellately and Ben Kiernan, eds., The Spectre of Genocide: Mass Murder in Historical Perspective (Cambridge: Cambridge University Press, 2003), and Martin Shaw, War and Genocide: Organized Killing in Modern Society (Cambridge: Polity Press, 2003). 
in his youth, as a Jew in occupied Poland, Raphael Lemkin fought in the underground resistance and in late 1944 published one of the most fateful works of political thought of the last century: Axis Rule in Occupied Europe: Laws of Occupation, Analysis of Government, Proposals for Redress. ${ }^{54}$ On the occasion of his birth centenary, Annan recalled that to describe an old crime, Lemkin had coined the new word 'genocide' in 1943, two years before the world became familiar with Auschwitz, Belsen, and Dachau, and 'almost single-handedly drafted an international multilateral treaty declaring genocide an international crime, and then turned to the United Nations in its earliest days and implored member states to adopt it' ${ }^{55}$

The Convention on the Prevention and Punishment of the Crime of Genocide, adopted by the General Assembly on 9 December $1948^{56}$ (one day before the Universal Declaration of Human Rights), was a milestone in defining genocide as a crime against humanity and thus a matter of universal criminal jurisdiction. Nevertheless, Annan continued, 'Article VI of the Convention, which binds the Parties to try persons charged with genocide before a national or international tribunal, has for all practical purposes remained a dead letter' ${ }^{57}$ But recent developments give hope: the crime of genocide was included in the statutes of the International Criminal Tribunals for Rwanda (ICTR), ${ }^{58}$ the former Yugoslavia (ICTY), ${ }^{59}$ and the

\footnotetext{
54 Reissued in 2005 by Lawbook Exchange.

55 United Nations, Press Release SG/SM/7842, 13 June 2001.

56 Lemkin was discovered weeping in a UN corridor at the news and described the Convention as an epitaph for his mother who had been among many members of his family killed in the Holocaust; Michael Ignatieff, ‘The Legacy of Raphael Lemkin', lecture delivered at the U.S. Holocaust Memorial Musuem Washington, 13 December 2001, available at

http://www.ushmm.org/conscience/analysis/details.php?content=2000-12-13, accessed 10 October 2008.

57 United Nations, Press Release SG/SM/7842, 13 June 2001.

58 See Kingsley Chiedu Moghalu, The Politics of Justice for Rwanda's Genocide (New York: Palgrave Macmillan, 2005); and Global Justice: The Politics of War Crimes Trials (Westport, Conn.: Praeger
} 
International Criminal Court (ICC). ${ }^{60}$

The war crime trials in Nuremberg and Tokyo were instances of victors’ justice. Yet by historical standards, both tribunals were remarkable for giving defeated leaders the opportunity to defend their actions in a court of law instead of being dispatched for summary execution. The ad hoc tribunals of the 1990s are important milestones in efforts to fill institutional gaps. While they have helped to bring hope and justice to some victims, combat the impunity of some perpetrators, and greatly enrich the jurisprudence of international criminal and humanitarian law, they have been expensive and time-consuming and contributed little to sustainable national capacities for justice administration. The 128-article Statute of the ICC was adopted at the conclusion of the UN Diplomatic Conference on the Establishment of the International Criminal Court in Rome in July 1998. Its adoption marked the culmination of a decade-long process initiated by the General Assembly in 1989 when it requested the International Law Commission to study the subject of the establishment of an ICC.

The ICC’s permanence, institutionalized identity, and universal jurisdiction is specifically designed to escape the tyranny of episodic and politically motivated investigations and selective justice. Only universal liability can arrest the 'drift to

International, 2006).

59 See Roger S. Clark and Madeleine Sann, eds., The Prosecution of International Crimes: A Critical Study of the International Tribunal for the Former Yugoslavia (New Brunswick, N.J.: Transaction, 1996).

60 See William A. Schabas, An Introduction to the International Criminal Court (Cambridge:

Cambridge University Press, 2001); and Bruce Broomhall, International Justice and the International Criminal Court: Between State Consent and the Rule of Law (Oxford: Oxford University Press, 2003). 
universalism'61_from the Nuremberg and Tokyo to the Yugoslavia and Rwanda tribunals, along with such other way-stations as the detention of Pinochet in Britainand replace it with institutionalized international criminal justice. Permanence also helps to cumulate and build on precedents.

The landscape of international criminal justice has changed dramatically in an astonishingly short period of time. ${ }^{62}$ In 1990, tyrants could have been reasonably confident of the guarantee of sovereign impunity for their atrocities. Today there is of course no guarantee of prosecution and accountability, but not a single brutish ruler can be totally confident of escaping international justice. The certainty of impunity is gone as the international criminal pursuit of serving presidents—Slobodan Milosevic, Charles Taylor, and Omar Hassan al-Bashir-along with Radovan Karadzic, the selfstyled head of Serb Republic, aptly demonstrates. The United Nations has been at the centre of this great normative, policy, and institutional advance.

\section{Tasks Ahead, Helping to Fill the Compliance Gap}

$\mathrm{R} 2 \mathrm{P}$ is a call to action on prevention, intervention, and post-conflict reconstructionnot the opening lines of a Socratic dialogue by diplomats. There is always a danger with radical advances that commitments at grand summits will suffer many a slip after the champagne flutes are stored. R2P is not just a slogan, and failure to act will make a mockery of the noble sentiments. The implementation and compliance gap, in short, is especially distasteful when mass murder and ethnic cleansing are the result of

\footnotetext{
${ }^{61}$ Gary Jonathan Bass, Stay the Hand of Vengeance: The Politics of War Crimes Tribunals (Princeton: Princeton University Press, 2000), p. 283.

62 See Richard Goldstone and Adam Smith, International Judicial Institutions: The Architecture of International Justice at Home and Abroad (London: Routledge, 2008).
} 
sitting on the sidelines.

The 2005 World Summit Outcome Document notwithstanding, some national diplomats insist that the heads of state and government rejected R2P in 2005. 63 The first danger thus is that of rollback: a shamefaced edging back from the agreed norm of 2005, a form of buyer's remorse. The need exists for continued advocacy and activism by civil society and concerned governments to remain steadfast and hold all governments' feet to the fire of individual and collective responsibility to protect atrisk populations. When Gareth Evans gave a lecture in July 2007 in Colombo about R2P and what it meant for Sri Lanka, he unleashed a storm of hostility that the 'socalled’ R2P norm ‘is nothing but a license for the white man to intervene in the affairs of dark sovereign countries, whenever the white man thinks it fit to do so'. Rather flatteringly, his 2007 visit to the island armed with R2P was compared to the coming of Christopher Columbus in 1492 and Vasco da Gama in 1498 armed with the Bible and the sword. ${ }^{64}$ One newspaper reported on 'crackpot ideas' like R2P that have been 'dismissed in academic and political circles as the latest "neo-imperialist" tactic of the big powers to intervene in the affairs of small nations’ ${ }^{65}$

Many regimes that fear the searchlight of international attention being shone on their

\footnotetext{
63 See the discussion in the Fifth Committee of the General Assembly at its $28^{\text {th }}$ meeting on 4 March 2008 ( UN document $\mathrm{GA} / \mathrm{AB} / 3837$ ) in the context of the publicly announced intention of the Secretary-General to appoint Professor Edward C. Luck as his special adviser with a focus on R2P. ${ }^{64}$ Quoted in Gareth Evans, 'Delivering on the Responsibility to Protect: Four Misunderstandings, Three Challenges and How to Overcome Them', Address to SEF Symposium 2007, 'The Responsibility to Protect (R2P): Progress, Empty Promise or a License for "Humanitarian Intervention”', Bonn, 30 November 2007. See also 'Int'l diplomatic coup to erode SL's sovereignty?' The Nation on Sunday (Colombo), 27 January 2008, at http://www.nation.lk/2008/01/27/newsfe5.htm, accessed 1 October 2008.

65 H. L. D. Mahindapala, 'Peace Secretariat calls for UN inquiry into Radhika Coomaraswamy, UN Under Secretary General, stuck in NGO scandal', Lanka Times, 29 January 2008, at http://www.lankatimes.com/fullstory.php?id=7218, accessed 1 October 2008.
} 
misdeeds will try to chip away at the norm until only a façade remains. The advocates of R2P cannot allow them to succeed. Better that the serially abusive regimes live with this fear of international intervention than that their people fear being visited by death and disappearance squads. Of course, members of such regimes could remove the cause of such fear by working, by themselves or in concert with international friends, to remove the causes and prevent a crisis from arising.

A second, opposite danger of rollback lies with the aggressive humanitarian warriors who gave 'humanitarian intervention' such a bad name in the first place. Iraq is the best example of why the authors and promoters of R2P fear certain 'friends' as much as opponents. ${ }^{66}$ Developing countries’ histories and their peoples' collective memories are full of past examples of trauma and suffering rooted in the white man's burden. The weight of that historical baggage is simply too strong to sustain the continued use of the language of humanitarian intervention.

The attachment of some analysts to that language is puzzling and problematic. It is puzzling, because the ICISS report argued explicitly and forcefully about the shortcomings of this terminology and the merits of a deliberate shift to the conceptual vocabulary of R2P. Many commentators simply ignore that, as if the argument has not been made. If they disagree with the report, they should confront the issue and explain why. The problematic element arises from the politics of the discourse. The ICISS report offered, and the High-Level Panel's and Secretary-General Kofi Annan's reports preferred, the R2P formulation because it was less confrontational

66 See Gareth Evans, 'Humanity Did Not Justify this War’, Financial Times, 15 May 2003; and Ramesh Thakur, 'The Responsibility to Protect and the War on Saddam Hussein', in Ramesh Thakur and Waheguru Pal Singh Sidhu, eds., The Iraq Crisis and World Order: Structural, Institutional and Normative Challenges (Tokyo: UN University Press, 2006), pp. 464-78. 
and polarizing, more likely to lead to a consensus across the bitter North-South divide. Humanitarian intervention approaches the topic explicitly from the Western interveners’ perspective and isolates and privileges 'intervention'. R2P is victimcentred and surrounds intervention with prevention before and rebuilding afterwards.

History proves that sovereignty and the norm of non-intervention notwithstanding, regional and global powers have intervened, repeatedly, in the affairs of weaker states. ${ }^{67}$ After the end of the Cold War, the Security Council experienced a spurt of enforcement activity within civil wars to provide international relief and assistance to victims of large-scale atrocities from perpetrator or failing states. ${ }^{68}$ From Liberia and the Balkans to Somalia, Kosovo, and East Timor, conscience-shocking humanitarian catastrophes were explicitly recognized as threats to international peace and security requiring and justifying forcible responses. When the Security Council was unable to act due to lack of enforcement capacity, it subcontracted the military operation to UN-authorized coalitions. And if it proved unwilling to act, sometimes groups of countries forged coalitions of the willing to act anyway even without Security Council authorization.

R2P offers developing countries better protection through agreed and negotiated-inadvance rules and roadmaps for when outside intervention is justified and how it may be done under UN authority rather than unilaterally. It will thus lead to the 'Gulliverization’ of the use of force by major global and regional powers, tying it with numerous threads of global norms and rules. Absent R2P, they have relatively

\footnotetext{
67 Weiss and Hubert, The Responsibility to Protect, pp. 49-77. See also Stephen Krasner, Sovereignty: Organized Hypocrisy (Princeton, N.J.: Princeton University Press, 1999).

68 Krasner, Sovereignty: Organized Hypocrisy, pp. 79-126.
} 
more freedom, not less, to do what they want. R2P is rooted in human solidarity, not in exceptionalism of the virtuous West against the evil rest.

Another danger from over-enthusiastic supporters is misuse of the concept in nonR2P contexts. A group of retired NATO generals including an ICISS commissioner, for example, used it to justify the first use of nuclear weapons to prevent nuclear proliferation. ${ }^{69}$ Others have used the label to refer to action to halt the spread of HIV/AIDS or to protect indigenous populations from climate change.

An admittedly tougher case arose in May 2008. Contradicting official sources, independent observers estimated that the death toll from Burma’s deadly Cyclone Nargis could surpass 100,000. The numbers displaced, homeless, and in desperate need of immediate humanitarian relief were as high as 1.5 million. Infuriatingly, the generals running - 'ruining' is more accurate - the country refused to open their borders to supplies of aid piling up around Burma. Bizarrely but predictably, they attached higher priority to going ahead with a sham referendum calculated to give their rule a veneer of legitimacy. ${ }^{70}$ Against this backdrop, French Foreign Minister Bernard Kouchner publicly suggested that the Security Council should invoke R2P.

At first blush, R2P would seem a strange principle to cite in order to deliver aid to the Burmese. Its provenance is protecting at-risk populations from mass-atrocity crimes. Broadening it to cover contingencies like nuclear proliferation, environmental vandalism, HIV/AIDS, and natural disasters may have the perverse effect of

\footnotetext{
69 Klaus Naumann, John Shalikashvili, Lord Inge, Jacques Lanxade, and Henk van den Breemen, Towards a Grand Strategy for an Uncertain World: Renewing Transatlantic Partnership (Lunteren, Germany: Noaber Foundation, 2007).

70 See Aung Zaw, ‘Ballot for a Tyrant', Guardian, 12 May 2008.
} 
weakening support for R2P when we face the next Rwanda tomorrow without materially helping the needy today.

Yet, the ICISS report indeed identified 'overwhelming natural or environmental catastrophes, where the state concerned is either unwilling or unable to cope, or call for assistance, and significant loss of life is occurring or threatened' as among the conscience-shocking situations justifying international intervention. ${ }^{71}$ This was not included in the 2005 World Summit decision, but ‘crimes against humanity’ were and, as defined in the 1998 ICC statute, would provide at least some of the necessary legal cover to force aside the recalcitrant generals and give help directly to afflicted people.

While the legal case for crimes against humanity was plausible, the politics against it were more compelling. Unless the Western powers were willing and able to launch another war in the jungles of Southeast Asia, it was better not to embark on this language and talk at all. This is why John Holmes, the UN's Under-Secretary-General for Humanitarian Affairs and a former British ambassador to France, described Kouchner’s call as unnecessarily confrontational. The British Cabinet Minister for International Development Douglas Alexander rejected it as 'incendiary’. ${ }^{72}$ Britain’s UN ambassador, John Sawers, said R2P did not apply to natural disasters. ${ }^{73}$

Invoking the coercive language of R2P would have riled the generals, who time and time again have proven themselves to be beyond shame, and undoubtedly they would

\footnotetext{
71 ICISS, The Responsibility to Protect, para. 4.20.

72 BBC News, May 9, 2008; downloaded on May 9 from http://news.bbc.co.uk/go/pr/fr//2/hi/uk_news/7391492.stm, accessed 1 October 2008.

73 Julian Borger and Ian MacKinnon, 'Bypass Junta’s Permission for Aid, US and France Urge', Guardian, 9 May 2008.
} 
have dug in their heels even more firmly. It would have risked antagonizing the Southeast Asian countries, whose political support was vital for communicating with the generals and persuading them to open up. It would have risked alienating China, India, and Japan, the three big Asian powers whose backing was essential for delivering any meaningful relief in Burma. ${ }^{74}$

In the end, R2P was not officially invoked; but it is not necessary for the Security Council to actually table a resolution to have an impact. It is plausible, but not verifiable at this juncture, that the ‘bad cop’ Kouchner made it possible for the 'good cops' of ASEAN, the Secretary-General, and humanitarians to be more effective than they might otherwise have been. In any event, the worst predictions for the aftermath of Cyclone Nargis proved overblown. On this occasion, at least, it was probably preferable not to go to the mat and reintroduce the North-South polarization over humanitarian intervention that ICISS worked so hard to overcome with the R2P formula.

Faced with firming opposition at all these levels, would the Western powers, already overstretched militarily in Afghanistan and Iraq and increasingly despised around the world for their belligerence as their default mode of engagement with regimes that do not kowtow to them, be prepared to use military force? If not, would they not damage their own political credibility and that of R2P by invoking it ineffectually? Analysts who pride themselves on their intellectual toughness are often limp in following

\footnotetext{
${ }^{74}$ Washington saw the sense of this and Secretary of State Condoleezza Rice called her Chinese and Indian counterparts, Foreign Ministers Yang Jeichi and Pranab Mukherjee, seeking their good offices in persuading Burma to adopt a more liberal approach towards foreign aid. 'Myanmar: U.S. seeks India's help', Hindu, May 11, 2008. It should be noted that Japan and India also rejected outside help after the Kobe earthquake and the tsunami respectively. And Washington rejected Cuban offers of help after Hurricane Katrina.
} 
through the logic of their calls to arms.

The urgent task was to provide humanitarian relief and reconstruction. Military intervention would not have helped and might have imperilled the delivery of such assistance. It would have also set off another war when our goal should be to end those already being fought and stop the threat of new ones erupting. And it would have jeopardized the chances of creating international consensus and generating the political will to take military action when mass killings break out again in some corner of the world, as will assuredly happen.

As the Burmese conundrum shows, to date our responses have typically been ad hoc and reactive, rather than consolidated, comprehensive, and systematic. We need a paradigm shift from a culture of reaction to one of prevention and rebuilding. Millions lost their lives during the Holocaust and in Cambodia, Rwanda, Srebrenica, and Darfur. After each we said ‘never again’ and then looked back each next time, with varying degrees of incomprehension, horror, anger, and shame, asking ourselves how we could possibly have let it all happen again.

As noted earlier, external military intervention to protect civilians inside sovereign borders without the consent of the state concerned differs from traditional warfare, collective security, and peace operations. The protection of victims from mass atrocities requires different guidelines and rules of engagement as well as different relationships to civil authorities and humanitarian actors. As Victoria K. Holt and Tobias C. Berkman argue, these differences need to be identified, articulated, and 
incorporated into officer training manuals and courses. ${ }^{75}$ For example, recalling the tragedy of Rwanda in 1994: how does a UN peace operation sent to supervise a peace agreement and process recast its task on the fly to prevent an unfolding genocide?

Operationalizing R2P with respect to the protection agenda in the field will mean adopting a bottom-up approach that brings together the humanitarian actors on the ground in conflict zones. ${ }^{76}$ Each context requires its own specific protection actions against threats to the people at risk there. The UN can provide the normative mandate at the global level for their protection and the forces necessary for intervention if need be. The action to prevent and rebuild has to be undertaken by UN agencies acting collaboratively with local civil society actors, NGOs, and representatives of the Red Cross and Red Crescent Movement. They can be brought together in a distinct protection cluster to assess needs and priorities for each vulnerable group requiring protection and identifying, in advance, the custom-tailored responses for prevention and rebuilding.

At the same time, opponents have a point in cautioning about the moral hazard that would result from over-enthusiastic recourse to international intervention. It can create perverse incentives for rebels and dissidents to provoke state retaliation to armed challenges. This was recognized by Kofi Annan just one year after his ‘challenge of humanitarian intervention'. In his Millennium Report, he conceded that

\footnotetext{
75 Victoria K. Holt and Tobias C. Berkman, The Impossible Mandate? Military Preparedness, the Responsibility to Protect and Modern Peace Operations (Washington, DC: Stimson Center, 2006). ${ }^{76}$ See Jaya Murthy, 'Mandating the Protection Cluster with the Responsibility to Protect: A Policy Recommendation Based on the Protection Cluster's Implementation in South Kivu, DRC', Journal of Humanitarian Assistance (October 5, 2008), downloaded from: http://jha.ac/2007/10/05/mandatingthe-protection-cluster-with-the-responsibility-to-protect-a-policy-recommendation-based-on-theprotection-cluster\%e2\%80\%99s-implementation-in-south-kivu-drcl, accessed 1 October 2008.
} 
his call for a debate on the challenge of humanitarian intervention had led to fears that the concept 'might encourage secessionist movements deliberately to provoke governments into committing gross violations of human rights in order to trigger external interventions that would aid their cause'. ${ }^{77}$ This too needs further research.

So too does the question of whether groups who constitute a minority in one country and are targeted for killings or ethnic cleansing based on their group identity are owed any responsibility by their kin state: China vis-à-vis overseas Chinese, say in Indonesia, or India vis-à-vis ethnic Indians in Fiji or Tamil Hindus in Sri Lanka, or Russia vis-à-vis Russians in the Baltic states, or Albania vis-à-vis Albanians around the Balkans, or the West vis-à-vis the whites in Zimbabwe. Thus, the Centre for International Governance Innovation (CIGI) has entered into a partnership with the UN University on a new project—drawing on historical and contemporary examples - that will explore how to apply R2P to the protection of national minorities. Inter-ethnic conflict and genocide have demonstrated the dangers of failing to protect people targeted by their fellow citizens. But unilateral intervention by a 'kin state' can lead to conflict within and between states. This presents a dilemma: while the world cannot stand by when minority rights are being trampled, the protection of national minorities should not be used as an excuse to violate state sovereignty. Therefore, how can R2P be applied to the protection of persons belonging to national minorities? Whose responsibility is it to protect such persons?

Yet another item on the research agenda would be to examine past cases of iconic examples of horrific atrocities and genocidal killings in twentieth-century history,

77 Kofi A. Annan, 'We the Peoples': The Role of the United Nations in the Twenty-first Century. Report of the Secretary-General (New York: UN, 2000), UN Document A/54/2000, para. 216. 
including the Holocaust, Bangladesh, Cambodia, Rwanda, and the Balkans. The goal would be to identify when and how R2P could have been invoked to legitimize international intervention and prevent or halt the atrocities. The advantage of such research is that these are all cases on which today there is agreement about the shameful failures of outsiders to take effective action in time. The research should help build a case load of R2P-type situations as a guide to future deliberations, evidence-based analyses, and robust action.

Civil society continues advocating on this issue. For example, a sub-unit within the World Federalist Movement's office in New York has been engaged in support of R2P for several years. Recognizing that the global endorsement of the norm in 2005 was but the prelude to translating it into timely action to prevent crises and stop atrocities, the Global Centre for R2P (GCR2P), based at The CUNY Graduate Center's Ralph Bunche Institute, was launched in February 2008 at the United Nations.

The Global Centre will work to make this doctrine a reality in collaboration with associated centres worldwide. Secretary-General Ban Ki-moon has welcomed the Global Centre’s establishment as ‘an effective advocate in the struggle to prevent the world’s most heinous mass crimes'. ${ }^{78}$ Supported by Australia, Belgium, Britain, Canada, France, the Netherlands, Norway, Rwanda, and other foundations and private donors, it will generate research, conduct high-level advocacy, and facilitate activities of those working to advance the R2P agenda.

\footnotetext{
${ }^{78}$ For this quote and other information, see $\underline{\text { http://www.GlobalCenter2p.org. }}$
} 


\section{Conclusion}

The R2P norm has become accepted with surprising rapidity. When post-election violence broke out in Kenya in early 2008, Francis Deng urged the authorities to meet their responsibility to protect the civilian population; ${ }^{79}$ and Archbishop Emeritus Desmond Tutu interpreted the African and global reaction to the Kenyan violence as 'action on a fundamental principle—-the Responsibility to Protect' ${ }^{80}$ The United Nations has played a key role in different ways and phases of the process, from initial articulation of the notion by an individual UN official, to a Secretary-General's openly challenging member states to replace the clearly broken consensus on the use of force in order to stop atrocities inside sovereign borders, the creation of an international commission in response, its recommendations directed in turn back at the UN policy community, and the endorsement of the norm by a summit of world leaders. Moreover, it illustrates well what the UN Intellectual History Project has called the 'three United Nations'—-member states, secretariats, and pertinent members of civil society-who in this case worked in tandem. ${ }^{81}$

If we return to our definition of global governance, R2P is about the changing conceptions of the appropriate relations between citizens and states in an interdependent and globalizing world: the norms, laws, and practices that constitute those relations, and the variety of civil society, governmental, and intergovernmental actors engaged in efforts to redefine and reconstitute the norms, laws, and practices.

\footnotetext{
79 Daily Press Briefing by the Office of the Spokesperson for the Secretary-General, 28 January 2008; available at http://www.un.org/News/briefings

80 Desmond Tutu, 'Taking the Responsibility to Protect', International Herald Tribune, 19 February 2008.

81 See Thomas G. Weiss, Tatiana Carayannis, and Richard Jolly, ‘The “Third” United Nations’, Global Governance vol. 15, no. 1 (2009), forthcoming; and Richard Jolly, Louis Emmerij, and Thomas G. Weiss, UN Ideas That Changed the World (Bloomington: Indiana University Press, 2009 forthcoming).
} 
Most of these efforts posit the United Nations as the central reference point, whether to emphasize or deny its indispensability. ICISS itself was careful to embed R2P within the context of evolving Security Council practices and customary international law. Based on state practice, Council precedents, established and emerging norms, and evolving customary international law, the International Commission on Intervention and State Sovereignty held that the proscription against intervention is not absolute.

As a universal organization, the United Nations is an ideal forum to seek consensus about normative approaches that govern global problems and would work best with a worldwide application of a norm. The host of problems ranging from reducing acid rain to impeding money laundering to halting pandemics clearly provide instances for which universal norms and approaches are required and emerging. At the same time, the UN is a maddening forum because dissent by powerful states or even coalitions of less powerful ones means either no action, or agreement only on a lowest common denominator. As we mentioned at the outset, watching Darfur's slow-motion genocide or the Burmese junta's ongoing abuses exacerbated in the aftermath of Cyclone Nargis illustrate the difficulty of giving operational meaning to the norm of the responsibility to protect. Normative progress is evident towards halting conscience-shocking murder and ethnic cleansing, but we still are unable to utter 'never again'. 